\title{
IMPROVING STUDENTS' SKILL IN WRITING NARRATIVE TEXT THROUGH ANIMATION MOVIE
}

\author{
KristianiLisma Vera Br Ginting ${ }^{1}$ \\ Universitas Prima Indonesia \\ Dinda Syafitri ${ }^{2}$ \\ Universitas Prima Indonesia \\ Cahaya Riama Yanti Nehe ${ }^{3}$ \\ Universitas Prima Indonesia \\ Nita Paskarina Manullang ${ }^{4}$ \\ Universitas Prima Indonesia \\ Sri NintaTarigan ${ }^{5}$ \\ Universitas Prima Indonesia \\ kristianiveraginting@gmail.com ${ }^{1}$
}

Submit, 30-11-2019 Accepted, 30-12-2019 Publish, 30-12-2019

\begin{abstract}
The purpose of this research is to find does the animation movies can improve students' skill and ability in writing narrative text at SMP Swasta TD Pardede Foundation at VII grade in academic year2018/2019. In this research, the researchers used classroom action research and was conducted in two cycles. Each cycles consist of four steps, there are: planning, action, observing and reflecting. This research used quantitative and qualitative research to collect the data, researchers conduct tests. The tests are pre-test and post-test.The result showed that the teaching students' skill in writing using video can improve students' skill in writing narrative text. An increase in mean scores indicates that there is an increase in students' skill. The student's pre-test score was 63.69; it increased to 72.50 in the first post-test up to 78.02 in the second post-test. From the result of the study, it can be concluded that teaching writing skill using animation videos can improve students' writing skill.
\end{abstract}

Keyword: narrative, animation movie 


\section{INTRODUCTION}

In some countries that consider English as a foreign language, writing in English is not easy for students. It can be seen from Heaton's theory (1988), sometimes writing is difficult to teach because it is complicated. Based on observations of students, some of them said that they were very bored and compiled, they gathered to write something in English, maybe caused by several process, mental and physical are carried at the same time. Moreover, writing also requires the students to elaborate the components of writing, there are vocabulary, content, organization to present writer ideas language use and mechanic which those work simultaneously to build some short text, at least one sentence with beginning on new line and it can be deal with some single event, idea and description. But, frequently, students meet the difficulties in writing:organized words to be paragraph, in expressing their ideas, language in grammatical sentences, coherences, cohesion, and so on.

The researchers found several problems students' writing skills, such as: they are still low in using grammar and low in vocabulary. That is why students are still difficult to express their ideas into written text. Researchers also found another problem that the projector was not yet available at the school and therefore the researchers themselves provided the tools and that became one of the strengths of this study.

For instance, sometimes they have many vocabulary but they are difficult to express the idea so it obstruct the students to build the paragraph. Further, determining topic or idea of writing is one of the problems that students mostly face when they want to start writing. This is first thing that a writer commonly needs to decide before starting the writing, either on the level of sentences or paragraphs. The responsibility lies on the teacher to improve their student's abilities specially in writing skill, so the students can write easily and creatively.

In the previous research conducted by Martono \& Asrori (2012), the writer gets some findings, animation movies asteaching media improves students' skill inwriting narrative text. Animation movieshelps the students in getting and developingtheir idea of writing. Animation movies can be media of teaching to improves the class situation. The students are interested toward English lesson especially writing narrative text get better after using animation movies. They were veryenthusiastic and not reluctant to write and do the tasks and taking part in the lesson. Another research by Puspitasari \& Murwani (2007) tells most of the students could not apply grammar, especially in simple pasttense and had less of vocabulary lists. The students' progress during the teaching and learning activity byteaching of a narrative text was good. The students' skill in writingnarrative of a text got improved. 
The other research written by Fadila (2015) tells in the pre-test, there were $38.88 \%$ students who passed the KKM and the mean score of pre-test was 64.72 . Then, the writer gave the movie and the students have to rewrite the movie story. The result of post-test 1 in cycle one, $55.55 \%$ who passed the KKM considering their mean score of the test gained 72.4. Next, to do the post-test 2, the writer gave the different movie from the cycle one. The result of post-test 2 in the second cycle shows that there were $86.11 \%$ who passed the KKM in which their mean score derived 83.1. It can be conclude that movie can improve students" writing skill in narrative text.

In this study, the writer choose animation movie as a media to improve students' writing skill in narrative text. The advantages of this research are the media is proven to increase students' curiosity to write everything on their minds. This strategy helps the students to comprehend more easily about narrative text, they can, the students found it easier to get an idea because they only rewrite the story in their word. The students had a lot of words based on the movie, so they onlyarranged the word into a good story.

\section{LITERARTURE REVIEW}

In this study, the researchers was decided to implement improvement writing by using animation movies because this strategy help the students to comprehend more easily what was being watch by them, the student more interested and less bored and the students also can hear how to pronounce and spell the words in that they are watched on the movie. By using this strategy, the students could remember the words longer because the movie they watched was more memorable instead of reading. Writing skills is one of four English skills besides listening, speaking and reading. Learning to write in schools has not been through the correct process. There are four process of writing, namely prewriting, drafting, revising and editing. Alexander, (1974) classified that writing skill can be well developed through exercise that have been controlled and assessed carefully. The summary of writing is not a barren academic exercise that is only useful for examination purpose. It can be used effectively to develop a student's writing ability.

The first research was conducted by Martono \& Asrori (2012) tells that the most common problem is the difficulty of students using grammar, limited vocabulary and difficulty in spelling correctly. This study used different data collection methods from the previous research. The quantitative data were obtained by calculating the score of the test.The researchers used oral test, written test and interview to collecting the data. To analyze the qualitative data, the researchers used steps to collect the data, collect the data from the scoring of the 
class, compare the sudents' score, calculate the percentage of the students' score, make the conclusion.

\section{RESEARCH METHOD}

The researchers used Classroom Action Research (CAR). In CAR, there is a cycle term which contains four stages of this research. The four stages are planning, acting, observing, and reflecting. By using animation videos with the title "White Snake" with eight minutes duration. In this research, there were two cycles. This research was conducted for about three months.

At the planning stage, the researchers give a lesson plan based on the result of problem identification. The next stage is acting; the researchers asked the student to watch the movie twice or after they got the meaning of the movie, then the researchers asked the students to retell that story by their own words in written as a narrative text. Make sure that the actions taken in implementation are in accordance with the initial goals. The observation is carried out in conjunction with the implementation phase. The reflection which is the stage to process the result data from the observation.From the results of this reflection the researchers will find out whether the animation movie was successful or not. If it does not meet the success criteria, then the researchers must revise the strategy and go to the next cycle.

\section{Figure Action Research}

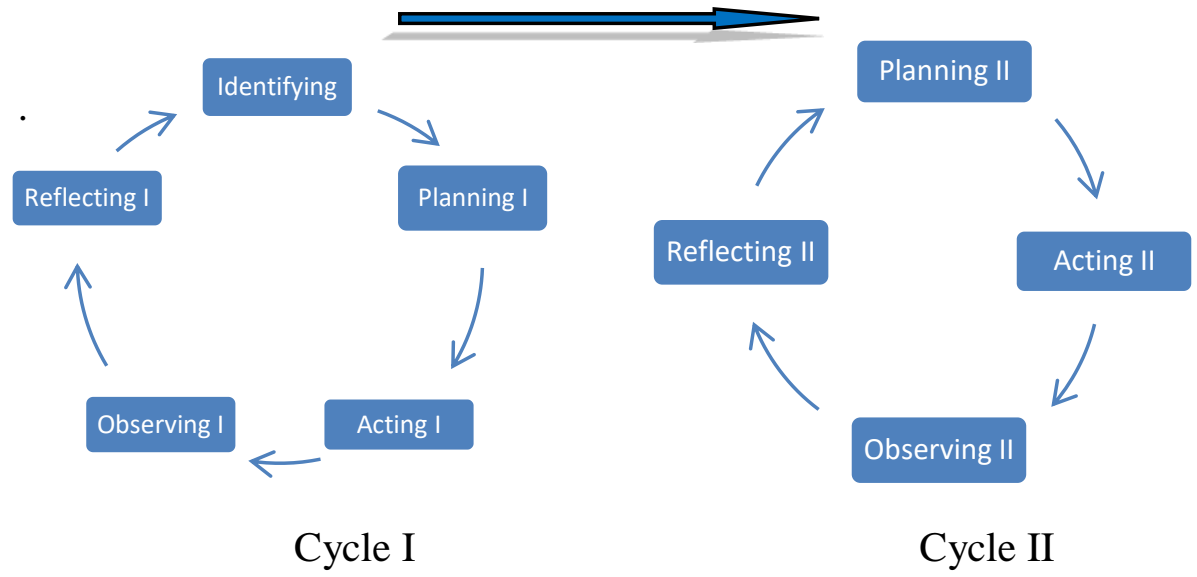

The result of the test would be analyzed and compare using statistical computation. This research used quantitative technique of collecting data. Quantitative data showed the difference of the cycle (before-after). Quantitative were obtained by calculating the score of the test. The researchers used oral test, written test and interview to collecting the data. To analyze the qualitative data, 
the researchers used steps to collect the data, collect the data from the scoring of the class, compare the sudents' score, calculate the percentage of the students' score, make the conclusion.The content of the writing narrative test include grammar, comprehension, content, and the organization of the sentence. Therefore, the researchers using formula to calculate the percentage of the percentage of students' skill in writing narrative. The pre-test and the post-test calculated with:

$$
X=\frac{\sum X}{N} \quad Y=\frac{\sum Y}{N}
$$

Where: $\mathrm{X}=$ is the pre-test score

$\mathrm{Y}=$ is the post- test score

$\mathrm{N}=$ is the numbers of sample

Calculate the percentage of the students' score into some categorized into five categories, there are: excellent, good, satisfactory, poor and fail.

Table 1 Description of Students' Score

\begin{tabular}{lll}
\hline Quantitative Ability & Categorized Ability & Ability \\
\hline $80-100$ & Excellent & Able \\
\hline $70-79$ & Good & Able \\
\hline $51-69$ & Poor & Unable \\
\hline $0-50$ & Fail & Unable
\end{tabular}

In this research, the researchers use Classroom Action Research Method. The action research consists of several stages: 1) Identifying, identifying the problems before start the planning. The problem referred to the factors making the low writing improvement of the student. The problem can be identified by using test, interview, and observation. 2) Planning. The writer prepared lesson plans, preparing the teaching aids (videos) and prepare the post-test to know whether students' writing skill improve or not. 3) Acting. In this part, the researchers used animation movie as a technique in the teaching and learning process. 4) Observing/ monitoring the action. The researchers monitored the students during teaching process in order to know whether it improvestheirwriting comprehension and class situation or not. 5) Reflecting. The researchers evaluated the result of the 
research, there are the improvement in writing comprehension and class situation to find out the positive result and weakness during the action.

\section{FINDING}

The animation video inspire the students to make narration easier because they can imagine about the story, then they write down on paper and the students were able to write using past tense correctly, it was shown by student's exercise in their work sheet. In the first cycle, the students' writing skill improved quite well. It was 63,69 in the pre-test. 71,50 in cycle I and 78,02 in cycle II. The increase of students' writing skill proficiency in each component in percentage from the beverage in every cycle can be seen in from the Diagram below:

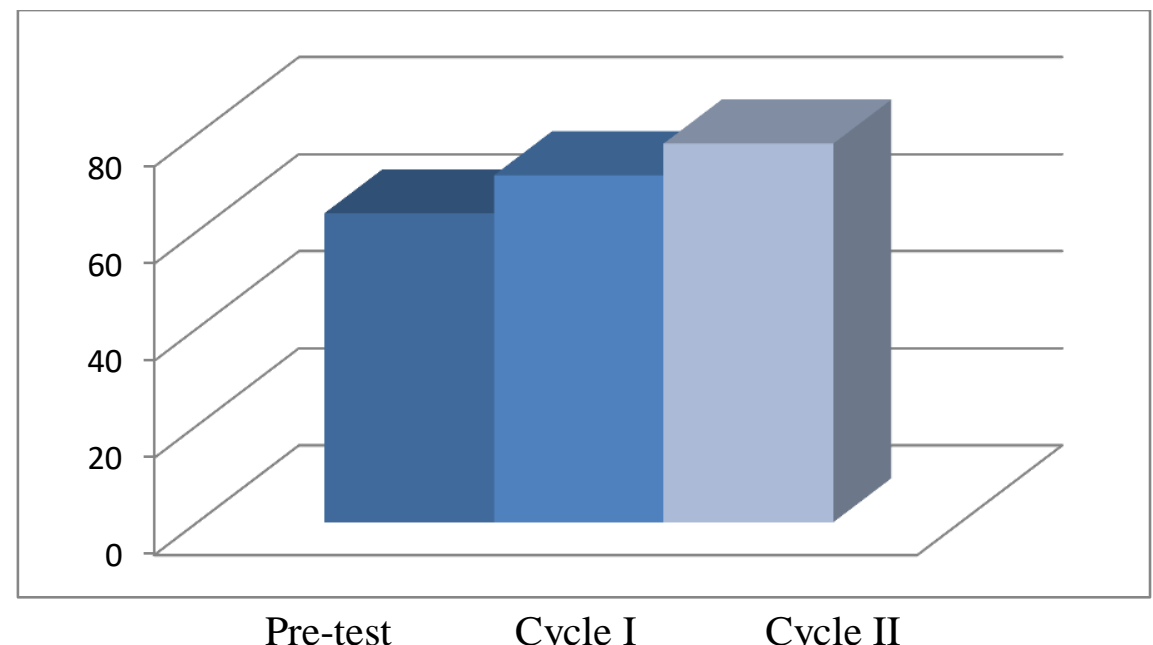

Figure. 1 Students’ Increase Writing Skill

\section{DISCUSSION}

The findings of the research show improvement from the pre-test up to the second cycle could be a reflection that watching animation videos was helped the students in their narrative text writing. The result shows that the students ability get betterin each cycle. This research consists of two cycles. Each cycle consist of two meetings. On the first meeting, the writers introduced about narrative text and explain about simple past tense. After that the writer asked the student to watch the movie with the title "White Snake" with eight minutes duration. After that the researchers asked the student to watch the movie twice or after they got the meaning of the movie, then the researchers asked the students to retell that story by their own words in written as a narrative text. 
The next meeting in cycle II researchers reviewed students' worksheet to ensure that students can write narrative text correctly. In the last meeting the researchers conducted the post-test. The positive results showed that there was an increase in students' writing skills in narrative text. In the pre-test, the researchers found that students' skill in writing is still low such the students still had difficulties in using grammar, the limited vocabulary that cause students difficult to write and express their idea from Bahasa into English, the mean score was 63,69 . After that in the cycle I they got improvement in writing narrative text and the mean score was 71,50 . Then in cycle II the students' can increase the score become 78,02 . The researchers found that the students' writing skill in narrative text through animation movie improve significantly.

This finding support by that graphic that shows improving students' narrative writing.According to Sadiman (2002), the message presented in the animationmovies can be a fact or fictitious, can be informative, educative, or instructive. It is informative, it means that much information from many experts in this world can be recorded in animation movies tape, so it canbe received by the students everywhere they are. By using modern animation techniques, the sciences are displayed become great and dramatic. The pictures and sounds that appear on movies that feature animated storylines also make the studentsnot bored, in order to stimulate the students to learn more and be encouraged to know and know the benefits of technology, As well as stimulating their interest to learn and enthusiastic about the stories that are shown in animated films especially in the learning process that supports the improvement of the students vocabulary.

\section{CONCLUSION}

Based on the research, it can be concluded using animation movie proven to improve students' skill in writing narrative text. In addition, learning process is more fun and it is better for the students to produce ideas that they see from the movie. This strategy is quite effective to make students confident and through this way students have a good comprehension about narrative text because of the visual effect of the movie.

\section{REFERENCES}

Alexander, L. G. (1974). Practice And Progress. Longman: Great Britain Arief, S. (2002). Media Pembelajaran dan Proses Belajar Mengajar, Developing Students' Writing Skill Of Narrative Texts. English Department Faculty Of Language And Arts: Semarang States University.

Fadila, S., F. (2015). Improving Students' Writing Skill In Narrative Text Fifth Edition. Oxford: Oxford UniversityPress.

Harmer, J. (2004). How to Teach Writing. Harlow: Pearson Education Limited 
Hornby, A., S. (1995). Oxford Advanced Learners Dictionary of Current English, Heaton. (1988). Writing English Language Tests, New York: Longman

Martono, R., A \& Muh, A. (2012). Improving Students' Skill In Writing Narrative Text Through Animation Movies. English Education Study Program Sebelas Maret University: Surakarta

Puspitasari, R., A \& Murwani. (2007). The Use Of Animation Movies For Through Movies. Department Of English Education Faculty OfTarbiyah And Teachers' Training UIN SyarifHidayatullah: Jakarta. 